\title{
EXPERIMENTAL STUDY ON CIRCULAR AND SQUARE CONCRETE FILLED STEEL TUBE COLUMNS SUBJECTED TO AXIAL COMPRESSION LOADS
}

\author{
D. R. Panchal ${ }^{1}$, V. P. Sheta ${ }^{2}$ \\ ${ }^{l}$ Assistant Professor, Department of Applied Mechanics, FTE-MSU, Vadodara, Gujarat, India \\ panchaldr@gmail.com \\ ${ }^{2}$ M.E. (Structural Engineering) Student, Department of Applied Mechanics, FTE-MSU, Vadodara, Gujarat, India \\ vpsheta63@gmail.com
}

\begin{abstract}
This paper investigates the behaviour of concentrically axially loaded circular and square high strength steel tube (Fe310 grade) columns filled with different grades (M20, M30 \& M40 etc.) of concrete. The effects of grade of concrete and composite action between the steel tube and the concrete core on axial load capacity are studied \& graphs of Axial load v/s vertical deflection (axial shortening curves) are plotted experimentally. Some important performance indices entitled as Ductility Index (DI), Strength factor (SI) and Concrete Contribution Ratio(CCR) are also evaluated and compared between the circular and the square shaped Concrete Filled Steel Tube (CFST) columns.By referring many research works, we can know firmly that confinement effect is restricted to short column only. So, we choose $300 \mathrm{~mm}$ length for all the specimens of $88.9 \mathrm{~mm}$ dia and $80 \times 80 \mathrm{~mm}$ size, to keep the columns stub only for getting benefit of confinement effect especially in circular sections.From the results, it has been noted that square columns have higher axial capacity when compared with circular columns of same resisting area under compression. Hence, size reduction for square column is possible. While ductility index for circular columns are quite better than square ones. Ultimate failure patterns are obtained by applying axial compression loads concentrically up to ultimate stage on circular and square CFST stub columns. as expected, the results shows a Local buckling i.e. crushing of concrete type of failure at supports. Ultimate axial load capacity of Concrete filled steel tubular columns are evaluated and compared experimentally as well as by calculations also, as per the guidelines suggested by EC4(Eurocode part-4, British Standards Institutions) code, which is the best suitable code for design of CFST columns amongst all other international codes for composite structure design. From the study it is concluded that, loads obtained by EC4 fits nearer to perfection and depicts the behaviour well enough by 15-20\% error with experimental ultimate loads. The results obtained by experimental and EC4 code are validated well with the previous scholar researchers too
\end{abstract}

Keywords: Concentrically Axially Loaded columns, Concrete-Filled Steel Tube (CFST) Stub Columns, High Strength Steel, Concrete Grade, Design Codes, Local Buckling, Performance Indices

\section{INTRODUCTION}

Steel members have the advantages of high tensile strength and ductility, while concrete members have the advantages of high compressive strength and fire resistance.

Composite members combine steel and concrete, resulting in a member that has the beneficial qualities of both materials. Two types of composite columns, those with steel sections encased in concrete and those with steel sections filled with concrete, are commonly used in buildings. Concrete-encased steel composite columns have become the preferred form for many seismic resistant structures. Under severe flexural overload concrete encasement cracks, resulting in reduction of stiffness, but the steel core provides shear capacity and ductile resistance to subsequent cycles of overload. (shanmugam and Lakshmi 2001 [1]).

In modern days, building design emphasizes on enhancing flexibility of the floor space byreducing the cross section of column size. Enhancing compressive strength of concrete on a smaller column gives more strength and more usable floor space. The use of high strength concrete in smaller column, endeavour to brittle failure. This would be prevented by reducing space of stirrup for higher ductility. However, this causes the stirrup to form a natural plane of separation between the confined concrete core and the unconfined concrete cover, the risk of a premature spalling of the concrete cover increases. This is one important reason why it is advantageous to use Composite Columns consisting of Concrete-Filled Steel Tubes (CFST) instead of traditional Reinforced Concrete Columns.

BurakEvirgen et al. (2014) [2]they investigated the compressive behavior of CFST section considering various cross-sectional shapes like circular, hexagonal, rectangular and square. Experimental study was carried out by varying $\mathrm{B} / \mathrm{t}$ (Breadth to thickness) ratio and grades of concrete. The obtained results of experimental study were compared with ABAQUS software. In this study, researchers observed that the concrete core of CFST resists the inward buckling of steel tube and steel tube provides better confinement to concrete core which results increase in the strength of CFST 
section. The study also shows that the ductility of the circular CSFT section is more than hexagonal, rectangular and square CFST sections.It is observed (E K Mohanraj; S Kandasamy; R Malathy [3]) that in long columns, general buckling and in short columns, crushing of concrete. The performance of CFST under sustained loads is different from ordinary reinforced concrete columns. In RCC columns, concrete experiences contraction as it setsduring its early age.

Recent trend of research in Structural engineering is to develop high strength materials to achieve more material strength to fulfil demands of high rise structures located in seismic prone areas, subjected to heavy loads.Fy310 possesses High yieldstrength(310Mpa) \& high ultimate strength $(450 \mathrm{Mpa})$. i.e. it is a high strength material against axial, bending and shear stresses compare to fy 210 \& fy 240 grade of steel. Grade 310 has combining excellent high temperature properties withgood ductility and weldability, is designed for high temperature service. It is also used for intermittent service at temperatures up to $1040^{\circ} \mathrm{C}$.

Here we would like to compare the difference of the axial load capacity of the circular and square CFST columns of high grade of steel for different grades (M20, M30 \& M40) of concrete. further, the performance indices named Ductility Index (DI), Strength Index (SI) and the Concrete Contribution Ratio (CCR) were evaluated and compared for the circular and square CFST columns. Finally, the design steps are presented along with calculated axial loading capacity of the CFST columns as per the EC4[6]design codes. Which is best suitable code for design of CFST columns amongst all other international codes for composite structure design.

Table -1: The Material properties of the Steel-tubes

\begin{tabular}{|c|c|c|c|c|c|}
\hline \multirow{2}{*}{ Section Type } & \multirow{2}{*}{ Grade } & \multicolumn{4}{|c|}{ Mechanical Properties } \\
\cline { 3 - 6 } & & YST & UTS & \multicolumn{2}{c|}{$\%$ of Elongation } \\
\cline { 3 - 6 } & & $(\mathrm{MPa})$ & $(\mathrm{MPa})$ & $<25.4 \mathrm{~mm}$ & $>25.4 \mathrm{~mm}$ \\
\hline \multirow{3}{*}{ RHS/SHS IS : 4923 } & YST 210 & 210 & 330 & 12 & 20 \\
\cline { 2 - 6 } & YST 240 & 240 & 410 & 10 & 15 \\
\cline { 2 - 6 } & YST 310 & 310 & 450 & 8 & 10 \\
\hline \multirow{3}{*}{ CHS IS : 1161 } & YST 210 & 210 & 330 & 12 & 20 \\
\cline { 2 - 6 } & YST 240 & 240 & 410 & 12 & 17 \\
\cline { 2 - 6 } & YST 310 & 310 & 450 & 12 & 14 \\
\hline
\end{tabular}

\section{EXPERIMENTAL PROGRAM}

The column was tested for static axial load with the following arrangements using Hydraulic Universal Testing Machine (200T). The schematic diagram and complete test set up used for all the specimens are shown in fig. $1 \& 2$. Three different grades of concrete i.e. M20, M30 \& M40 has been used of two different shapes (circular \& square) of CFST columns. The columns were fixed at both ends and axial compressive load was applied. A pre-load of about 5 $\mathrm{kN}$ was applied to hold the specimen upright. Dial gauge was used to measure longitudinal deformations of the columns. The load was applied in small increments of 50 $\mathrm{kN}$. At each load increment, the deformations were recorded. All specimens were loaded up to ultimate load.

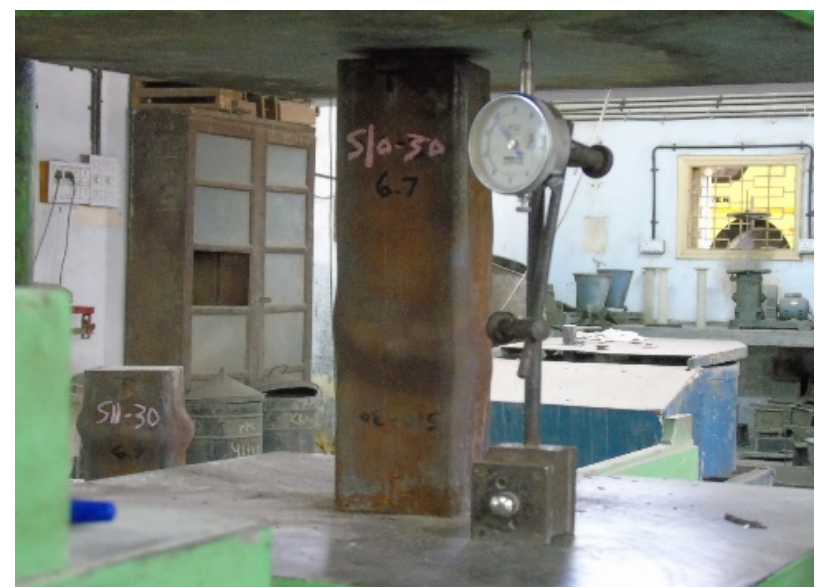

Fig -1: Exp. Setup for Square CFST Columns

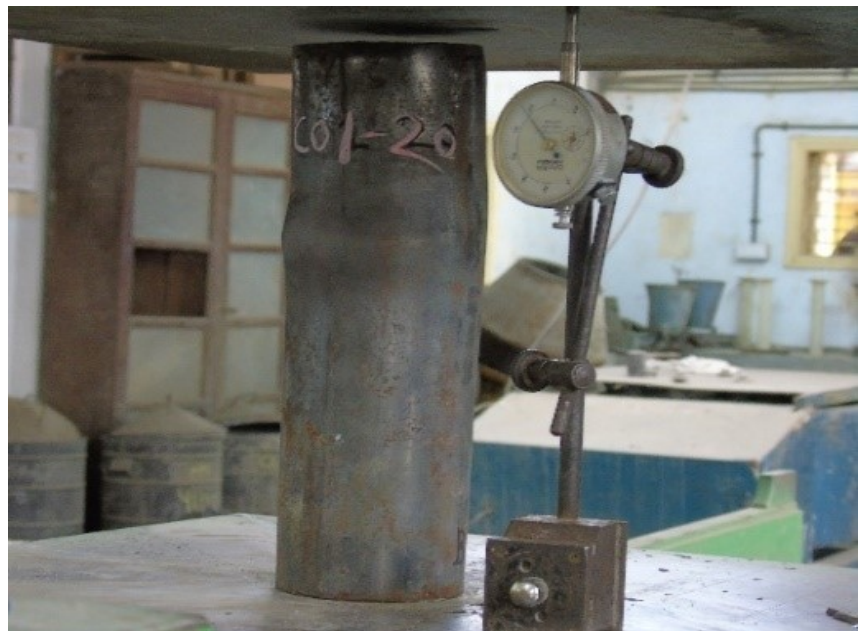

Fig -2: Exp. Setup for Circular CFST Columns

Table -2: Concrete Strengths

\begin{tabular}{|c|c|}
\hline Grade of concrete & $f_{c k}\left(\mathrm{~N} / \mathrm{mm}^{2}\right)^{*}$ \\
\hline M20 & 25 \\
\hline M30 & 34.4 \\
\hline M40 & 44.4 \\
\hline
\end{tabular}

* indicates average strength of the three cubes @ end of 28 days curing. 
Table -3: Specimen Properties

\begin{tabular}{|c|c|c|c|c|c|c|c|c|}
\hline $\begin{array}{l}\text { sr } \\
\text { no }\end{array}$ & $\begin{array}{c}\text { shape of } \\
\text { CFST column }\end{array}$ & size of column & thickness & length & $\begin{array}{l}\text { type } \\
\text { of MS }\end{array}$ & $\begin{array}{c}\text { type of } \\
\text { concrete }\end{array}$ & $\begin{array}{c}\text { no of } \\
\text { specimens }\end{array}$ & designation \\
\hline \multirow{3}{*}{1} & & \multirow{3}{*}{$88.9 \mathrm{~mm}$ dia } & \multirow{3}{*}{$4.8 \mathrm{~mm}$} & \multirow{3}{*}{$300 \mathrm{~mm}$} & \multirow{3}{*}{ fy3 10} & M20 & \multirow{3}{*}{$3 \times 6=18$} & $\mathrm{C} 01-20$ to $\mathrm{C} 06-20$ \\
\hline & & & & & & M30 & & $\mathrm{C} 07-30$ to $\mathrm{C} 12-30$ \\
\hline & & & & & & M40 & & $\mathrm{C} 13-40$ to $\mathrm{C} 18-40$ \\
\hline \multirow{3}{*}{2} & & \multirow{3}{*}{$80 \times 80 \mathrm{~mm}$} & \multirow{3}{*}{$4.8 \mathrm{~mm}$} & \multirow{3}{*}{$300 \mathrm{~mm}$} & \multirow{3}{*}{ fy3 10} & M20 & \multirow{3}{*}{$3 \times 6=18$} & $\mathrm{~S} 01-20$ to S06-20 \\
\hline & & & & & & M30 & & $\mathrm{S} 07-30$ to $\mathrm{S} 12-30$ \\
\hline & & & & & & M40 & & $\mathrm{S} 13-40$ to $\mathrm{S} 18-40$ \\
\hline
\end{tabular}

\section{EXPERIMENTALRESULTS}

Axial shortening curves (i.e. axial compression load vs vertical deflection) for the circular and the squareCFST specimens are shown in Charts 1-3b. As shown in these figures, all the circular and square CFST columns have not definite axial shortening during the initial linear stage during loading process, which shows the composite action between steel tube and the concrete core.

The average axial load capacity for the different grades of concrete are shown in chart 4 . the axial load capacity is very much higher for the square CFST columns than the circular ones with same area of steel \& same resisting area under compression, as expected. However, the axial load capacity is gradually increased for both of the square \& circular CFST columns when the grade of concrete is increased from M20 to M30 \& M40. Axial shortening values at ultimate load for hollow as well as CFSTscircular columns are significantly more than square ones for all three grades of concrete. While these values decreases for both circular \& square CFST columnswhen grade of concrete is increased from M20 to M40, which we can see from the charts-(1 to $3 b)$ very easily.

To compare the ductility, strength enhancement and role of concrete part in the CFST columns, some important parameters are defined as below and evaluated for the different filling concrete grade i.e. M20, M30and M40. Which are Ductility Index (DI), Strength Index (SI) and Concrete Contribution Factor (CCR) respectively.

$\mathrm{DI}=\frac{\delta_{85 \%}}{\delta_{u}}$

$\mathrm{SI}=\frac{\mathrm{p}_{u, \text { filled }}}{\mathrm{A}_{s} f_{y}+\mathrm{A}_{c} f_{c k}}$

$\mathrm{CCR}=\frac{\mathrm{p}_{u, \text { filled }}}{\mathrm{p}_{u, \text { hollow }}}$

Here, $\mathrm{p}_{u \text {, filled }}$ is the ultimate load capacity of infilled steel tubes while $\mathrm{p}_{u \text {,hollow }}$ is the ultimate load capacity of the steel tubes without filling, $\delta_{u}$ is the axial shortening of CFST specimens at the ultimate stage; $\delta_{\mathbf{8 5} \%}$ is the axial shortening of CFST specimenswhen the load falls to $85 \%$ of the ultimate load.

The strength enhancement index (SI) can be defined as the ratio the axial load capacity of the CFST section to the sum of the strengths of the steel tube and the concrete combined. Role of the concrete part in axial load capacity of CFST columns are shown by CCR i.e. Ratio of the ultimate load capacity of in-filled to the un-filled steel tubes. The relationships between the constraining factor and the ductility index, strength enhancement index and the concrete contribution ratio are shown in Charts-5 to 8 .

The increase in the DI is $20-25 \%$ higher for the circular CFST columns than the square ones. Contrary to the DI, SI and CCR are much higher for Square CFST columns.

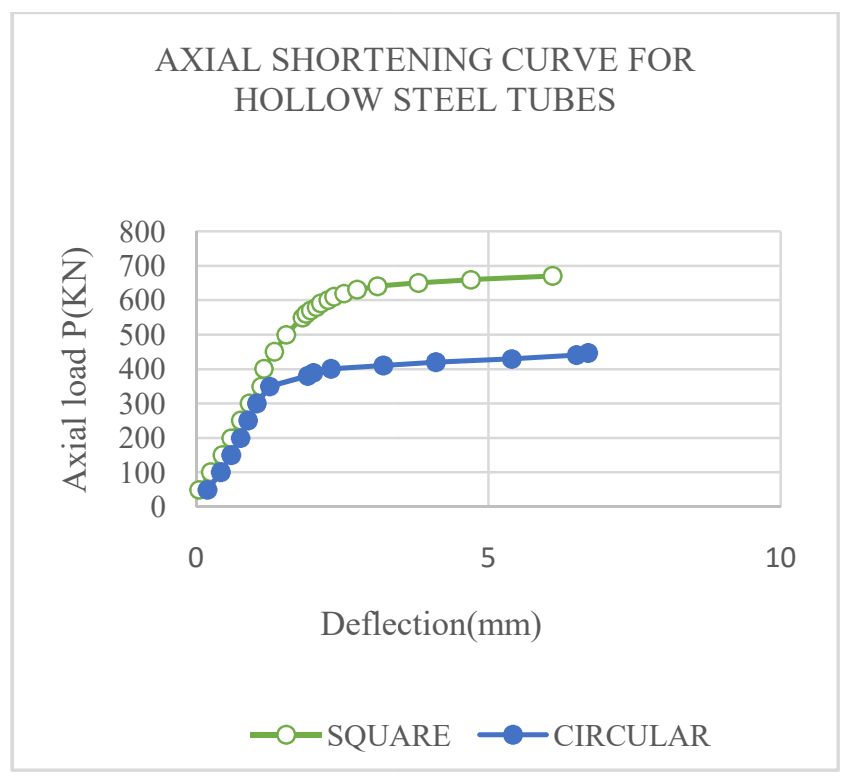

Chart -1: 


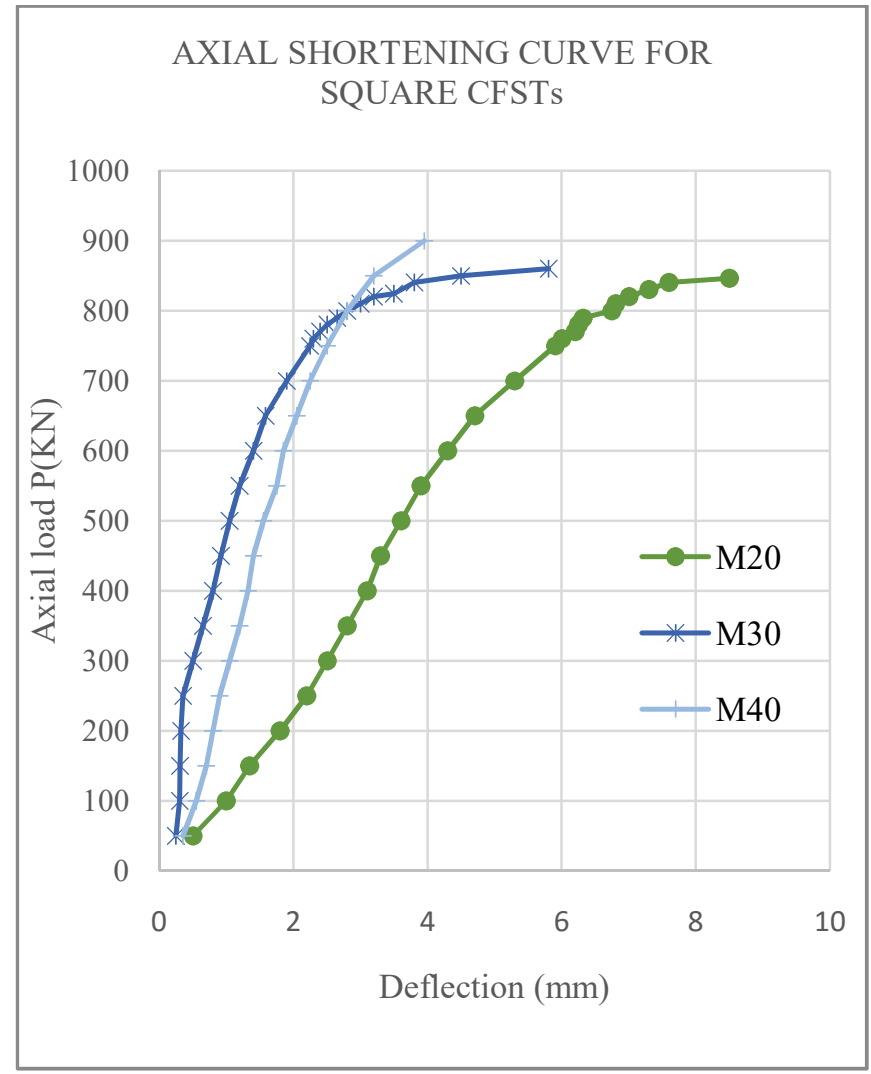

Chart -2a:

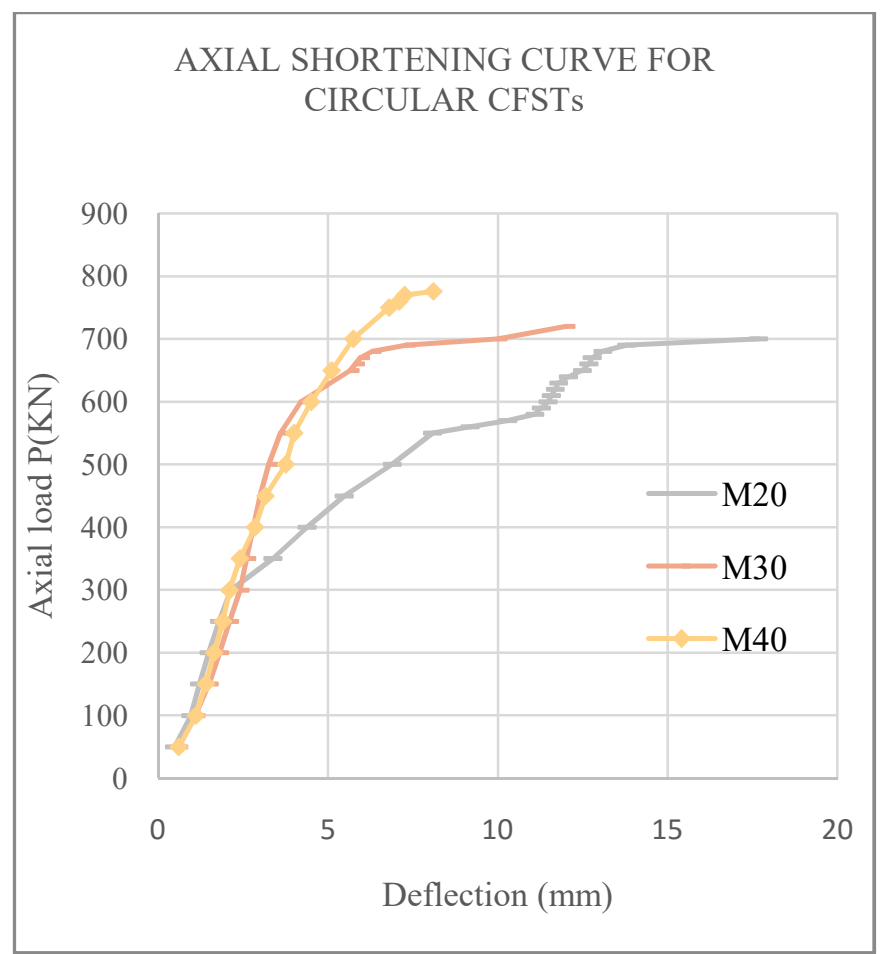

Chart - 2b

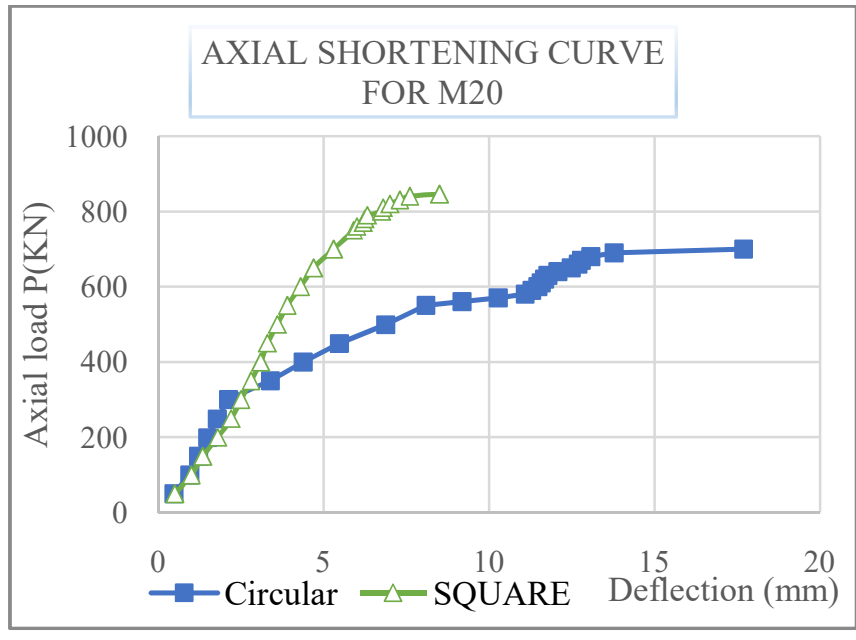

Chart -3a:

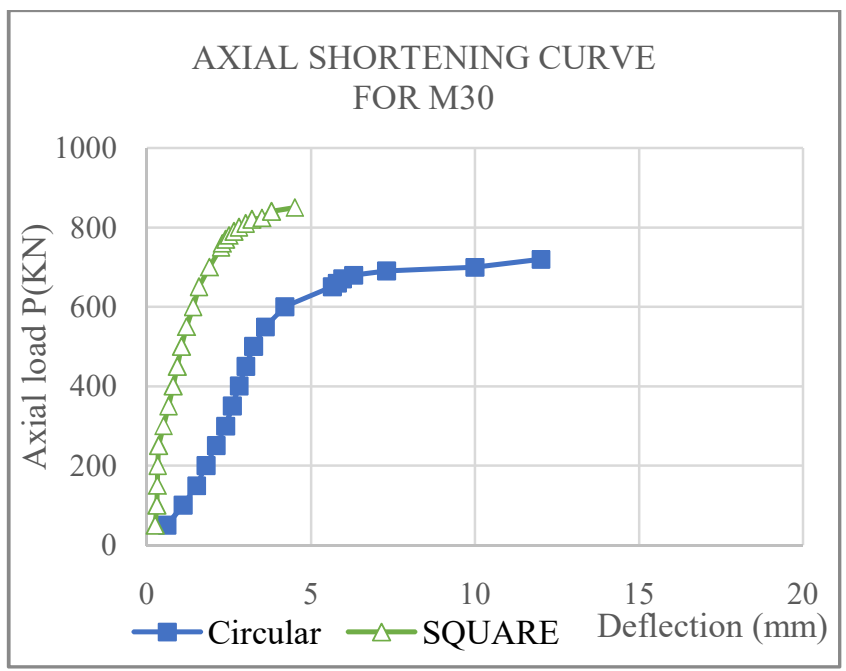

Chart -3b:

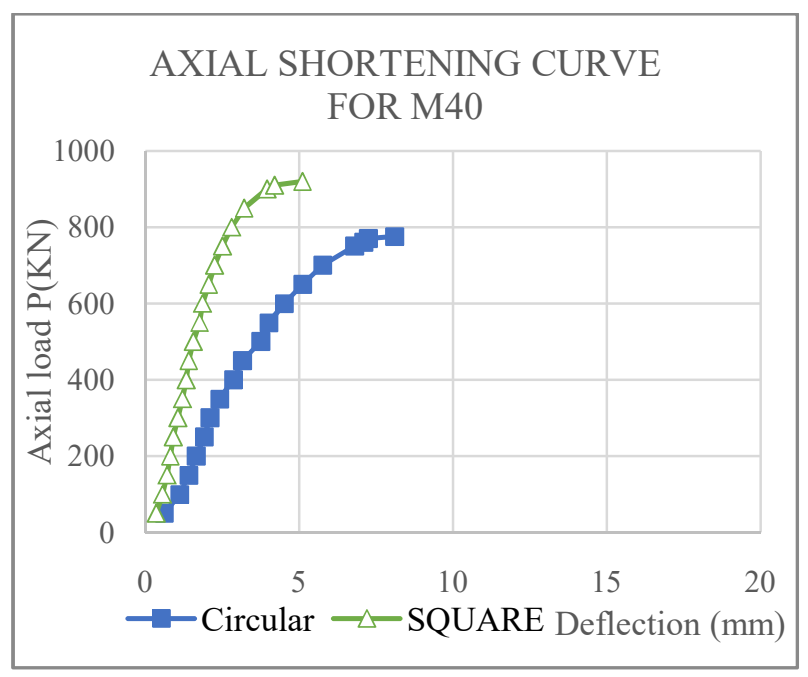

Chart -3c: 


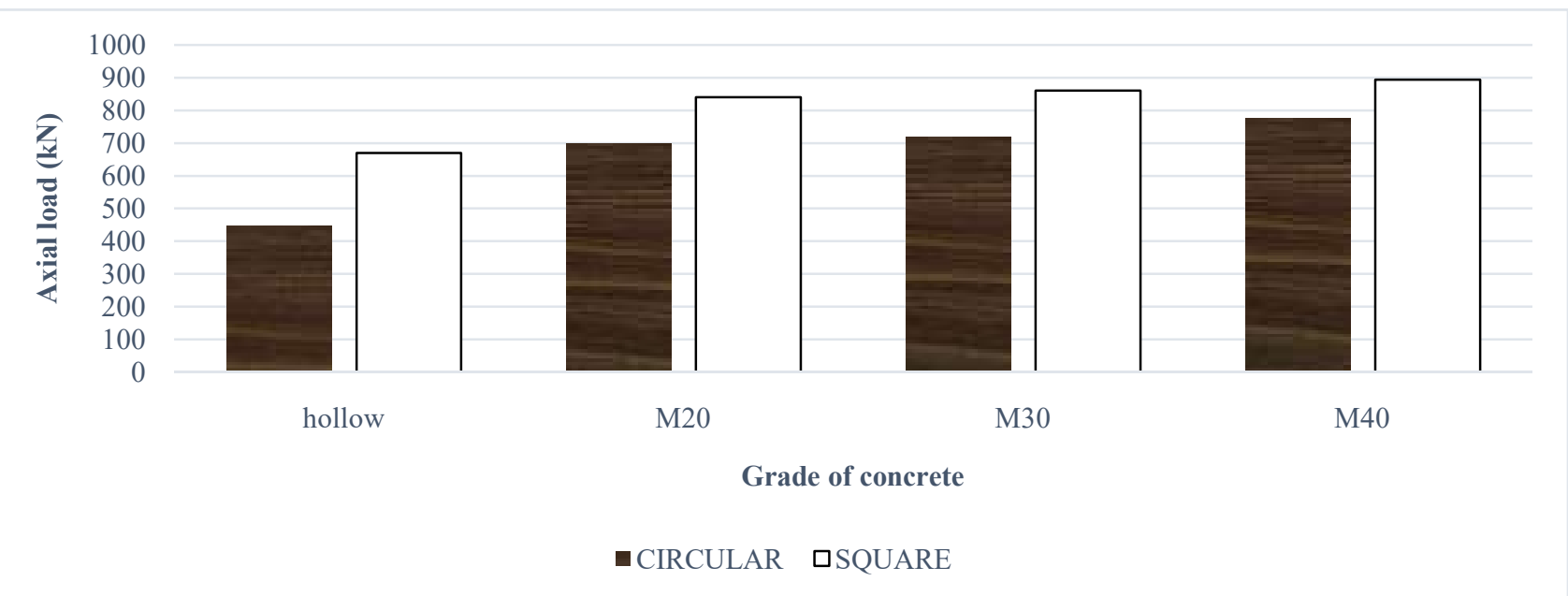

Chart -4: The average axial load capacity for the different type of grades of concrete

Table -4: Measured circular specimen test results

Table -5: Measured square specimen test results

\begin{tabular}{|c|c|c|c|c|c|c|c|c|c|}
\hline Specimen & $\begin{array}{c}\text { Weight } \\
(\mathrm{kg})\end{array}$ & $\begin{array}{c}\text { fck } \\
(\mathrm{N} / \mathrm{mm} 2)\end{array}$ & $\operatorname{Pue}(k N)$ & $\begin{array}{c}\text { Avg } \\
\text { Pue }(k N)\end{array}$ & Specimen & $\begin{array}{c}\text { Weight } \\
(\mathrm{kg})\end{array}$ & $\begin{array}{c}\text { fck } \\
(\mathrm{N} / \mathrm{mm} 2)\end{array}$ & Pue(kN) & $\begin{array}{c}\text { Avg } \\
\text { Pue }(k N)\end{array}$ \\
\hline C01-20 & 6.4 & \multirow{6}{*}{20} & 700 & \multirow{6}{*}{700} & S01-20 & 6.8 & \multirow{6}{*}{20} & 842 & \multirow{6}{*}{840} \\
\hline $\mathrm{C} 02-20$ & 6.3 & & 700 & & S02-20 & 6.8 & & 840 & \\
\hline C03-20 & 6.4 & & 710 & & S03-20 & 6.8 & & 840 & \\
\hline C04-20 & 6.2 & & 700 & & S04-20 & 6.7 & & 856 & \\
\hline $\mathrm{C} 05-20$ & 6.4 & & 740 & & S05-20 & 6.8 & & 846 & \\
\hline C06-20 & 6.3 & & 740 & & S06-20 & 6.7 & & 846 & \\
\hline C07-30 & 6.3 & \multirow{6}{*}{30} & 710 & \multirow{6}{*}{720} & S07-30 & 6.7 & \multirow{6}{*}{30} & 810 & \multirow{6}{*}{860} \\
\hline C08-30 & 6.3 & & 720 & & S08-30 & 6.6 & & 856 & \\
\hline C09-30 & 6.3 & & 740 & & S09-30 & 6.6 & & 846 & \\
\hline C10-30 & 6.3 & & 720 & & $\mathrm{~S} 10-30$ & 6.7 & & 860 & \\
\hline C11-30 & 6.1 & & 722 & & $\mathrm{~S} 11-30$ & 6.7 & & 860 & \\
\hline $\mathrm{C} 12-30$ & 6.2 & & 710 & & $\mathrm{~S} 12-30$ & 6.6 & & 840 & \\
\hline C13-40 & 6.4 & \multirow{6}{*}{40} & 790 & \multirow{6}{*}{776} & $\mathrm{~S} 13-40$ & 6.7 & \multirow{6}{*}{40} & 888 & \multirow{6}{*}{894} \\
\hline C14-40 & 6.3 & & 762 & & $\mathrm{~S} 14-40$ & 6.8 & & 920 & \\
\hline C15-40 & 6.4 & & 796 & & $\mathrm{~S} 15-40$ & 6.7 & & 908 & \\
\hline C16-40 & 6.3 & & 800 & & S16-40 & 6.7 & & 882 & \\
\hline $\mathrm{C} 17-40$ & 6.4 & & 770 & & $\mathrm{~S} 17-40$ & 6.8 & & 870 & \\
\hline C18-40 & 6.3 & & 776 & & $\mathrm{~S} 18-40$ & 6.7 & & 894 & \\
\hline
\end{tabular}

Table -6: Average Values of Performance Indices

\begin{tabular}{|c|c|c|c|c|c|c|c|}
\hline $\begin{array}{c}\text { GRADE OF } \\
\text { CONCRETE }\end{array}$ & \multicolumn{4}{|c|}{ CIRCULAR CFSTs } & \multicolumn{3}{c|}{ SQUARE CFSTs } \\
\cline { 2 - 8 } & $\boldsymbol{D I}$ & $\boldsymbol{S I}$ & $\boldsymbol{C C R}$ & $\boldsymbol{C F}$ & $\boldsymbol{D I}$ & $\boldsymbol{S I}$ & $\boldsymbol{C C R}$ \\
\hline $\mathbf{2 0}$ & 0.74 & 1.37 & 1.57 & 0.84 & 0.62 & 1.53 & 1.26 \\
\hline $\mathbf{3 0}$ & 0.7 & 1.28 & 1.61 & 0.61 & 0.55 & 1.41 & 1.28 \\
\hline $\mathbf{4 0}$ & 0.65 & 1.26 & 1.74 & 0.47 & 0.53 & 1.36 & 1.33 \\
\hline
\end{tabular}


Table -7: Performance Indices

\begin{tabular}{|l|l|l|l|l|l|l|l|}
\hline Specimen & DI & SEI & CCR & Specimen & DI & SEI & CCR \\
\hline C01-20 & 0.74 & 1.35 & 1.57 & S01-20 & 0.62 & 1.52 & 1.26 \\
\hline C02-20 & 0.42 & 1.35 & 1.57 & S02-20 & 0.78 & 1.51 & 1.25 \\
\hline C03-20 & 0.64 & 1.37 & 1.59 & S03-20 & 0.62 & 1.51 & 1.25 \\
\hline C04-20 & 0.68 & 1.35 & 1.57 & S04-20 & 0.66 & 1.54 & 1.28 \\
\hline C05-20 & 0.70 & 1.43 & 1.66 & S05-20 & 0.65 & 1.53 & 1.26 \\
\hline C06-20 & 0.63 & 1.43 & 1.66 & S06-20 & 0.63 & 1.53 & 1.26 \\
\hline C07-30 & 0.63 & 1.26 & 1.59 & S07-30 & 0.55 & 1.35 & 1.21 \\
\hline C08-30 & 0.78 & 1.28 & 1.61 & S08-30 & 0.53 & 1.42 & 1.28 \\
\hline C09-30 & 0.54 & 1.31 & 1.66 & S09-30 & 0.40 & 1.41 & 1.26 \\
\hline C10-30 & 0.70 & 1.28 & 1.61 & S10-30 & 0.37 & 1.43 & 1.28 \\
\hline C11-30 & 0.70 & 1.28 & 1.62 & S11-30 & 0.64 & 1.43 & 1.28 \\
\hline C12-30 & 0.68 & 1.26 & 1.59 & S12-30 & 0.46 & 1.40 & 1.25 \\
\hline C13-40 & 0.66 & 1.29 & 1.77 & S13-40 & 0.67 & 1.36 & 1.33 \\
\hline C14-40 & 0.36 & 1.24 & 1.71 & S14-40 & 0.53 & 1.41 & 1.37 \\
\hline $\mathrm{C} 15-40$ & 0.71 & 1.30 & 1.78 & S15-40 & 0.66 & 1.39 & 1.36 \\
\hline C16-40 & 0.48 & 1.31 & 1.79 & S16-40 & 0.53 & 1.35 & 1.32 \\
\hline C17-40 & 0.71 & 1.26 & 1.73 & S17-40 & 0.52 & 1.33 & 1.30 \\
\hline C18-40 & 0.65 & 1.27 & 1.74 & S18-40 & 0.61 & 1.37 & 1.33 \\
\hline
\end{tabular}

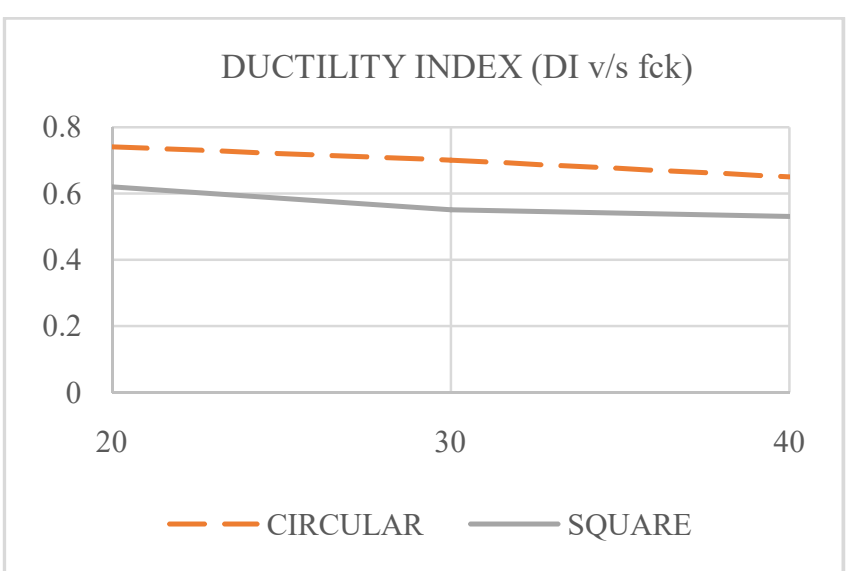

Chart -5: Variation of Ductility Index

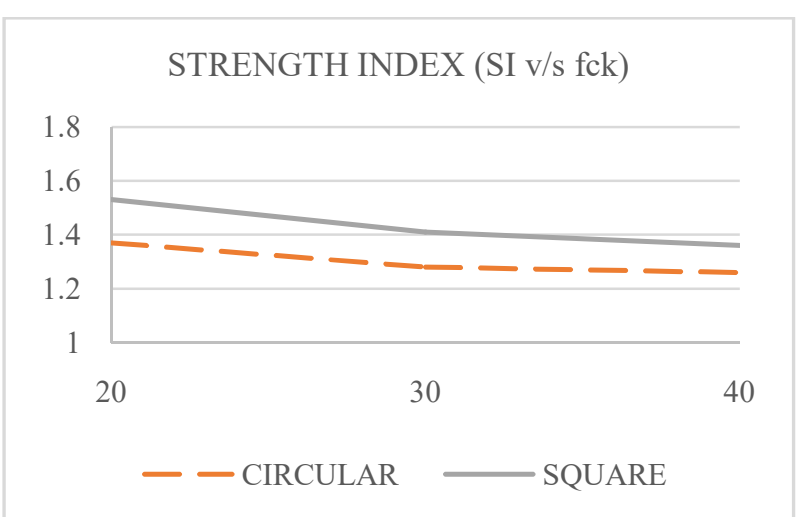

Chart -6: Variation of Strength Index

\section{CONCRETE CONTRIBUTION RATIO} (CCR v/s fck)

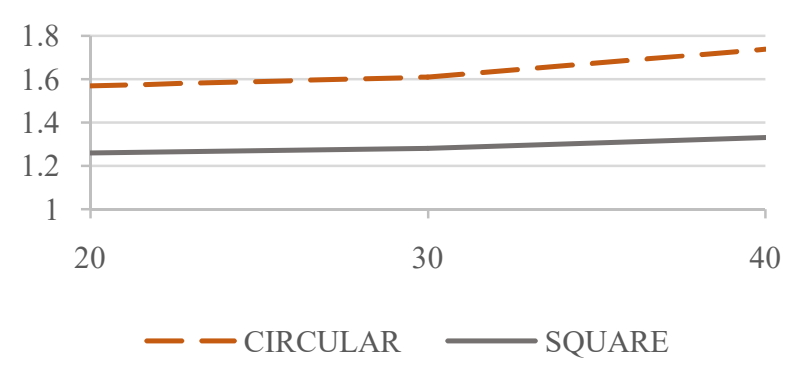

Chart -7: Variation of Concrete Contribution Ratio CONFINEMENT FACTOR (CF v/s fck)

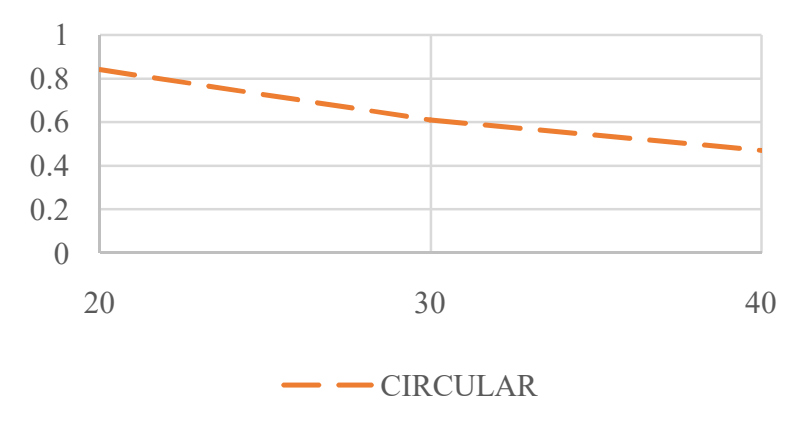

Chart -8: Variation of Confinement Factor 


\section{DESIGN CODES}

Eurocode 4:

\subsection{Concrete filled Rectangular Hollow Sections (RHS)}

The plastic resistance of a concrete filled rectangular hollow sectionis given by

$\mathbf{N}_{\mathrm{pl}, \mathrm{Rd}}=\mathbf{A}_{\mathrm{a}} \mathbf{f}_{\mathrm{y}} / \boldsymbol{\gamma}_{\mathrm{a}}+\mathbf{A}_{\mathrm{s}} \mathbf{f}_{\mathrm{sk}} / \gamma_{\mathrm{s}}+\mathbf{A}_{\mathrm{c}} \mathbf{f}_{\mathrm{ck}} / \gamma_{\mathrm{c}} \ldots$ (1)

Where,

$A_{a}$ is the area of the steel section

$A_{S}$ is the area of the reinforcement

For ease of expression, $f_{y} / \gamma_{a}, f_{s k} / \gamma_{s}$ and $f_{c k} / \gamma_{c}$ are presented asdesign strengths of the respective materials as $f y d$, $f$ sdand $f c d$ respectively.

By simplifying eq. 1

$\mathbf{N}_{\mathrm{pl}, \mathrm{Rd}}=\mathbf{A}_{\mathrm{a}} \mathbf{f}_{\mathrm{yd}}+\mathbf{A}_{\mathrm{s}} \mathbf{f}_{\mathrm{sd}}+\mathbf{A}_{\mathrm{c}} \mathbf{f}_{\mathrm{cd}} \ldots$ (2)

\subsection{Concrete filled Circular Hollow Sections (CHS)}

For composite columns with concrete filled circular hollowsections, the increased resistance of concrete due to the confining effect of thecircular hollow section may be included. The resistance of a concrete filled circular hollow sectionto compression may increase by upto $15 \%$ under simple axial loads when theeffect of tri-axial confinement is considered, which is restricted to short column only. EC4 considers confinement effects for circular sections when relative slenderness $(\lambda)$ has value less than 0.5 . It is the only code that treats the effects of long-term loading separately.

The plastic compression resistance,

$N_{p l, R d}=A_{a} f_{y d} \eta_{2}+A_{s} f_{s d}+A_{c} f_{c d}\left(1+\eta_{1}\left(t f_{y} / d f_{c k}\right)\right) \ldots(3)$

Where,

$\mathrm{t}$ is the wall thickness of the steel hollow section in $\mathrm{mm}$.

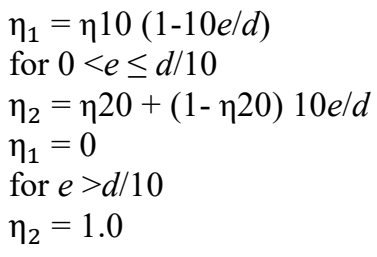

The basic values $\eta 10$ and $\eta 20$ depend on the nondimensionalslenderness ratio $\lambda$.

Table -8: Axial Load carrying Capacity of CFST columns

\begin{tabular}{|c|c|c|c|c|c|}
\hline $\begin{array}{c}\text { Shape of } \\
\text { CFST column }\end{array}$ & size & fck & Ntest & NEC4 & Ntest / NEC4 \\
\hline & & & $(\mathrm{kN})$ & $(\mathrm{kN})$ & \\
\hline & \multirow{3}{*}{$88.9 \mathrm{~mm}$} & M20 & 700 & 583 & 1.20 \\
\hline & & M30 & 720 & 632 & 1.14 \\
\hline & & M40 & 776 & 656 & 1.18 \\
\hline & \multirow{3}{*}{$80 \times 80 \mathrm{~mm}$} & M20 & 840 & 704 & 1.19 \\
\hline & & M30 & 860 & 749 & 1.15 \\
\hline & & M40 & 894 & 784 & 1.14 \\
\hline
\end{tabular}

\section{FAILURE MODE OF SPECIMENS}

Local buckling found at top \& bottom in the case of circular $\&$ square hollow steel tubes respectively. Failure of all CFST specimens are of compression type (i.e. crushing of concrete at top or bottom) only because all the specimens are short only (fig. 3 to 8 ) i.e. $\mathrm{L} / \mathrm{D}=3.75<4.0$. fig. 6,7 which shows similar type of expected failure of circular $\&$ square CFSTs for all three different grades of concrete.

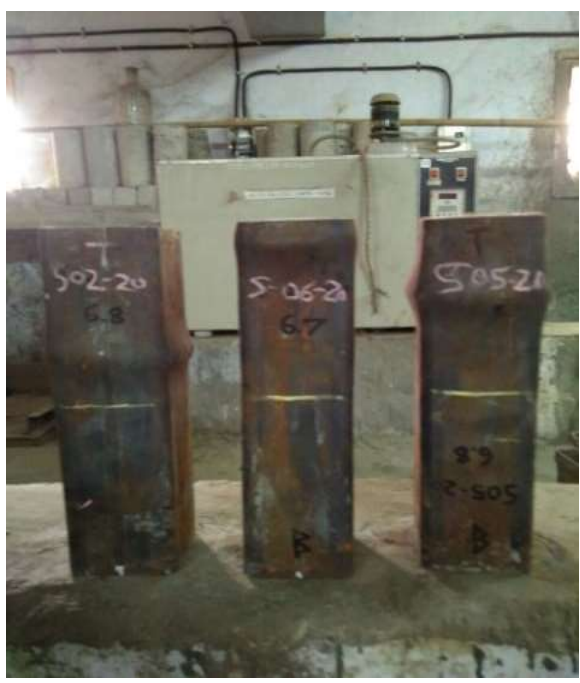

Fig -3: M20 grade CFST square columns 


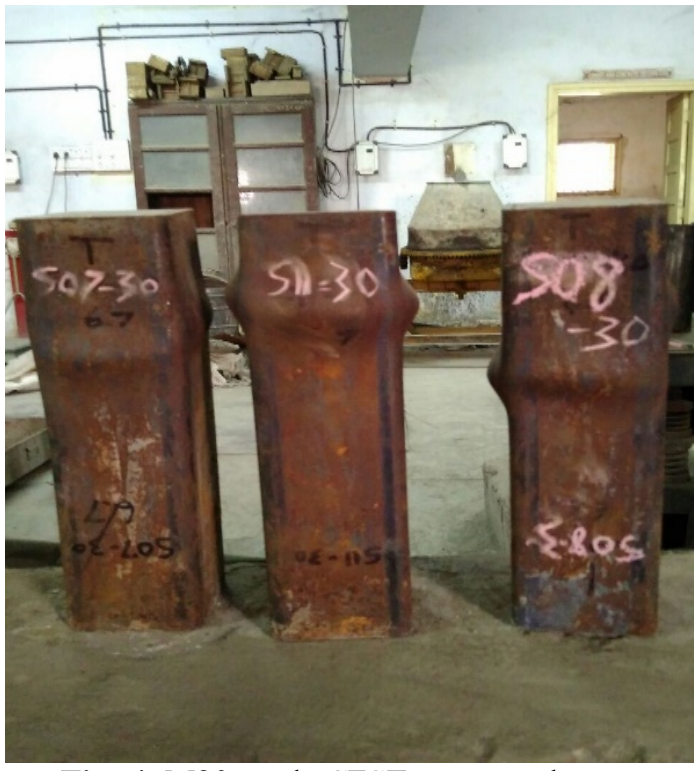

Fig -4: M30 grade CFST square columns

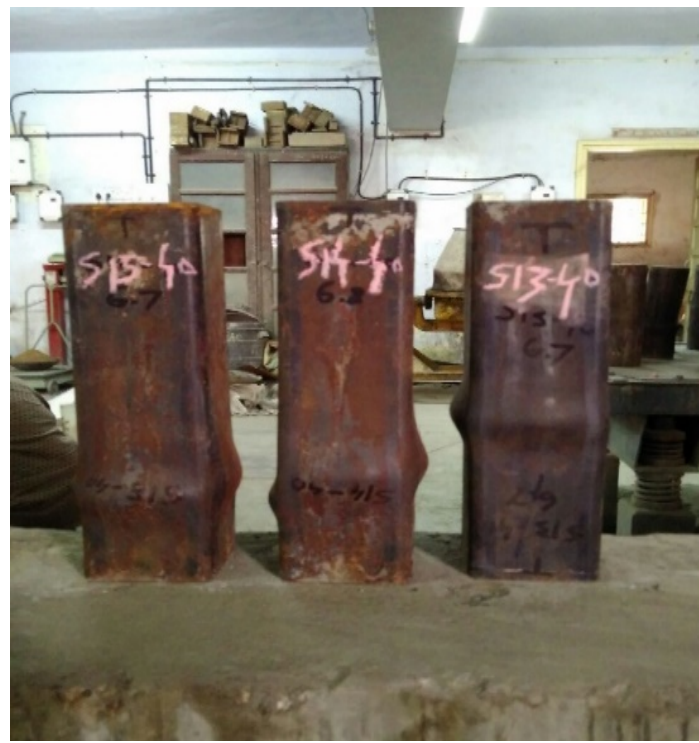

Fig -5:M40 grade CFST square columns

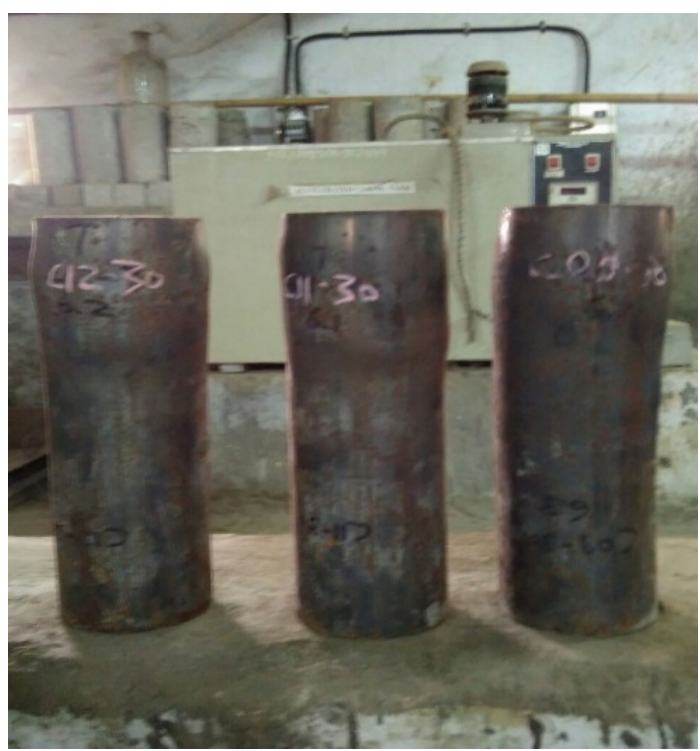

Fig -6:M20 grade CFST circular columns

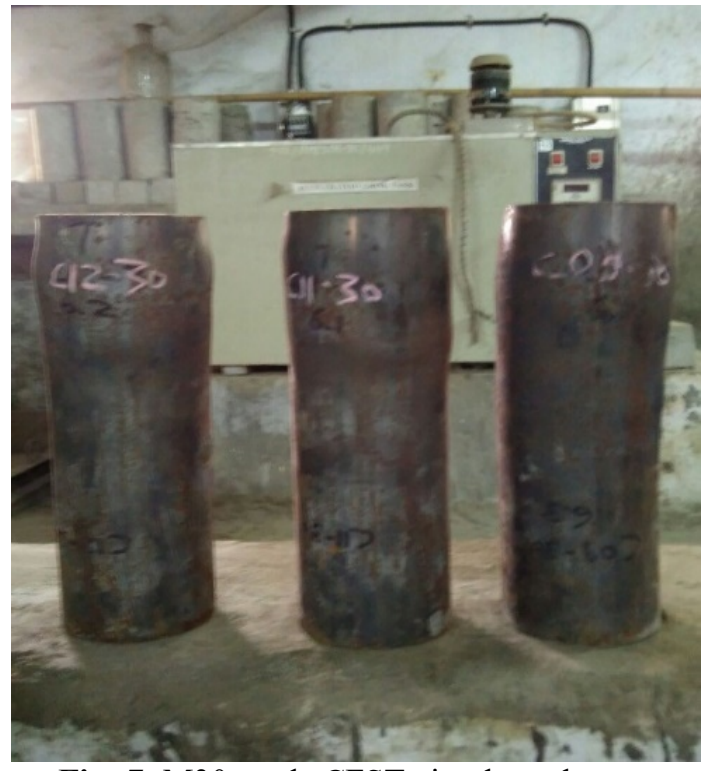

Fig -7: M30 grade CFST circular columns

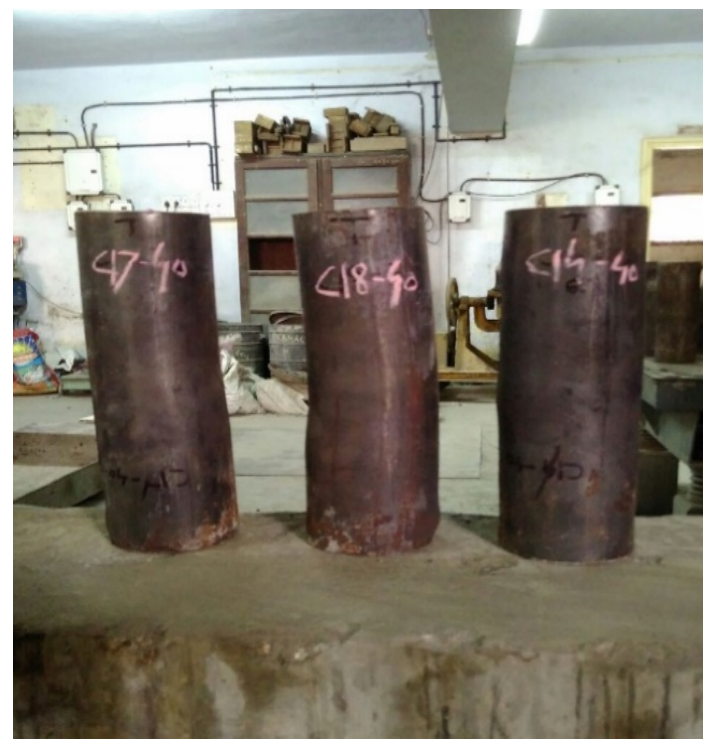

Fig -8: M40 grade CFST circular columns

\section{CONCLUSIONS}

- Ultimate load $(\mathrm{Pu})$ for square shape CFST sections are quite higher compared to circular ones. Although, they were kept of same thickness \& same resisting area under compressive load.

- It can be observed that the strength to weight ratio of 80 mm hollow square column is about $35 \%$ more than that of $88.9 \mathrm{~mm}$ hollow circular column. Therefore, about $30 \%$ of steel can be saved when square columns are used to obtain the same load capacity instead of circular columns.

- By increasing grade of concrete, decrement in ultimate axial shortening value for CFSTs. i.e. stiffness increases with increase in concrete strength but columnsfail due to crushing of concrete for all the specimens.

- Ultimate axial shortening values for circular CFSTs are quite large than square ones for all grades of concrete. i.e. ductility index of circular CFSTs are better. 
- By increasing grade of concrete, Concrete Contribution Ratio(CCR) increases while Strength Index(SI) decreases. The increase in the Ductility Index(DI) is 20$25 \%$ higher for the circular CFST columns than the square ones.

- By comparing experimental ultimate axial load capacity of CFST columns with analytical (i.e. by Eurocode4) it is concluded that results are vary by $15-20 \%$ error. Which is not depicts perfect results but acceptable due to validation by other researchers too.

\section{REFERENCES}

[1] Shanmugam, N E and Lakshmi, B 2001. State-of-the art report on steel-concrete composite columns. Constructional Steel Research, 57: 1041-1080

[2] BurakEvirgen, KivancTaskin, 2014 Structural behaviuor of concrete filled steel tubular Sections (CFT/CFSt) under axial compression, research article in THIN WALLED STRUCTURES.

[3] Concrete-filled RHS Sections", Journal of Constructional Steel Research, 2002, Vol. 58, No. 2, pp. 353-72

[4] Giakoumelis, G. and Lam, D. (2004), “Axial Capacity of Circular Concrete-filled Tube Columns" Journal of Constructional Steel Research, 2004, Vol. 60, No. 7, pp.1049-68.

[5] Eurocode 4. Design of composite steel and concrete structures. Part 1.1, General rules and rules for buildings (with UK national application document), DD ENV 1994-1-1. London (UK): British Standards Institution; 1994.

[6] Johnson R. P. (2004), "Composite Structures of Steel and Concrete", Vol. 1, Blackwell Scientific Publications, U.K.

[7] Lu, Z.H. and Zhao, Y.G., "Mechanical Behaviour and Ultimate Strength of Circular CFT columns Subjected to Axial Compression Load", The $14^{\text {th }}$ World Conference on Earthquake Engineering, Beijing, China, 2008.

[8] Han, L.H., "Tests on Stub Columns of Concrete-filled RHS Sections", Journal of Constructional Steel Research, 2002, Vol. 58, No. 2, pp. 353-72.

[9] Yang, H., Lam, D. and Gardner, L. "Testing and Analysis of Concrete-filled Elliptical Hollow Sections", Engineering Structures,2008, Vol. 30, No. 12, pp. 37713781 .

\section{BIOGRAPHIES}

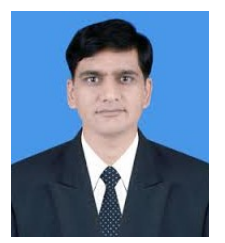

Dr. D. R. Panchal is currently Assistant Professor in Applied Mechanics and Structural Engineering Department at Faculty of Technology and Engineering, The Maharaja Sayajirao University of Baroda, Vadodara. He obtained his Ph.D. Civil degree in 2011 from Faculty of Technology and Engineering, M. S. University of Baroda. He has more than 13 years of teaching, research and corporate experience. He has published more than 40 research papers in various International \& National Journals, Conferences and Seminars. He has guided sixteen M.E. thesis in the field of Structural Engineering.

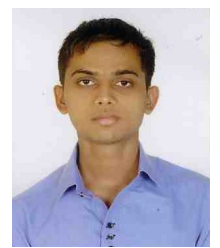

V. P. Sheta, Graduated in the year 2014 from MSU, Vadodara. Persuing M.E. in Structural Engineering at MSU. Also doing Dissertation under the guidance of Dr, D R Panchal 